\title{
A Systematic Review on the Intervention Using Exercise Gaming to reduce Childhood Obesity
}

\author{
Aminuddin $\mathrm{NA}^{\mathrm{a}}$, Azit $\mathrm{NA}^{\mathrm{a}}$, Daud $\mathrm{F}^{\mathrm{a}}$ \\ ${ }^{a}$ Faculty of Medicine, Universiti Kebangsaan Malaysia, Hospital Canselor Tuanku Muhriz, Jalan Yaacob Latif, \\ Bandar Tun Razak, 56000 Cheras, Wilayah Persekutuan Kuala Lumpur
}

\begin{abstract}
The worsening trend of childhood obesity is a global public health issue. Digital technology evolution is a contributing factor towards physical inactivity and obesity among children. In order to overcome this growing problem, exercise games have been introduced in early eighties to ameliorate this obesogenic environment. Exercise games utilize innovative technologies that provide an interactive environment, requiring gestures and body movements to simulate on-screen gameplay. The objective of this review is to assess the effectiveness of exercise gaming intervention in managing childhood obesity. A systematic review was performed. Six articles examining exercise video games impact on weight management among children published between January 2013 and December 2017 in the English language were selected from a total of 54 articles identified through five major search engines. Majority of the researchwas conducted in developed countries particularly in the United States whereby some developing countries had started with small-scale researches in this area. The result indicated that there was a significant increase in physical activity level, reduction of BMI, reduced adipose tissue composition and a positive psychological impact after the intervention of exercise games. However, the impact of exercise games on physiological and metabolic parameters were inconclusive and requires further study. In conclusion, exercise games are the effective way to combat childhood obesity, along with other modules of lifestyle.
\end{abstract}

KEYWORDS: Childhood Obesity, Pediatric Obesity, Exercise Game, Active Video Game, Weight Loss.

\section{INTRODUCTION}

The rapidly emerging childhood obesity is a worrying trend globally. With the revolution of digital technology, children spend more time on the technological devices such as televisions, smartphones, computers and tablets. At present, many studies revealed that children are being exposed to these devices at an early stage of life, as early as during the infancy period ${ }^{1,2,3}$. This later developed the raising concern on the inappropriate screen time among the children ${ }^{4}$. Furthermore, the

Corresponding Author

Dr. Faiz Daud

Community Health Department,

Faculty of Medicine,

Universiti Kebangsaan Malaysia,

Hospital Canselor Tuanku Muhriz

Jalan Yaacob Latif, Bandar Tun Razak,

56000 Cheras, Wilayah Persekutuan Kuala Lumpur

Tel No : +6019-271 2008

Email : faizdaud@ppukm.ukm.edu.my increase in screen time per day were reported to be related to obesity in various studies, and with a demonstrated dose response relationship between the hours spent and adiposity ${ }^{5}$. The possible explanation for obesity development includes reduction in physical activities ${ }^{6,7}$, unhealthy $\operatorname{diet}^{4}$, and lack of sleep among children who were involved in excessive daily screen time ${ }^{8}$. Moreover, the development of adiposity will increase the sedentary habits which will become a vicious cycle for obesity, leading to non-communicable diseases later in their adulthood. ${ }^{8,9}$

According to World Health Organization (WHO), the prevalence of childhood obesity is alarmingly increasing, especially in developing countries. ${ }^{10} \mathrm{~A}$ global prevalence study by De Onis et al. revealed that the prevalence of obesity is increasing at $2.5 \%$ from the previous decade, in which the developing countries contributed a major proportion of the obese children (35 million). ${ }^{11}$ In addition, numerous longitudinal studies in the past have also 
demonstrated that childhood obesity is linked with technology usage. ${ }^{12}$

Therefore, in order to subdue this growing problem, exercise games have been introduced in the early 80 's to ameliorate this obesogenic environment. ${ }^{13}$ They utilize innovative technologies that provide an interactive environment requiring gestures and body movements to simulate on screen game play. ${ }^{14}$ Interestingly, exercise gaming is obtaining much attention among health researchers in managing childhood obesity. Numerous clinical trials were conducted worldwide to get a stronger evidence on its potential benefit. Nevertheless, previous studies were limited in developed countries and may possess different outcomes than less developed regions. Moreover, previous studies were limited in terms of sample size and was shaded by the limitation of the study designs. ${ }^{15}$ Therefore, this review is aimed to provide latest discussion on recently conducted studies with the objective to evaluate the effectiveness of exercise games in reducing obesity among children.

\section{MATERIALS AND METHODS}

\section{Data source}

This systematic review began by searching the intervention for combating obesity among children. We encountered the emerging intervention which is exercise gaming. Following that, the definition of "exercise games" was generated, progressing to screening of articles by using Prisma checklist (Refer Figure 1 Prisma Checklist Algorithm). Exercise game was defined as an interactive digital programme or video game that involves rigorous physical movement.

One author initiated the topic while another two authors performed a literature search independently which were retrieved and compiled via online citation manager (Mendeley software). Five search engines were used in this study-EBSCOHOST, COCHRANE, OVID, PUBMED and SCOPUS by inserting keywords: "Childhood Obesity" OR "Pediatric Obesity" AND "Exergame" OR “Exercise Game" OR "Active Video Game" OR "Exertainment" AND "Weight Loss" OR "Reduce Weight". The articles were searched from January 2013 to December 2017. The primary intention was to capture most or all of the research articles written in English on exercise games published in peer-reviewed journals. All authors read and approved the final manuscript. The inclusion criteria for this study were as follows: (1) study design of randomized controlled trial (RCT) and observational study, (2) latest article published for the past 5 years (January 2013 to December 2017), (3) used exercise games as intervention, (4) original article and not the review of other studies. We excluded articles which involved an adult as their sample in the study.

A total of 54 articles were identified through 5 databases searching. We removed duplicate articles and left another 35 articles. The abstracts of 35 articles were examined and 16 publications on exergame research that specifically targeted obesity prevention were identified. The inclusion criteria for this study were then applied. A total of 16 fulltext articles assessed for eligibility. 10 records excluded from the study due to various reasons, such as 2 were review articles, 1 involved adult sample, 1 was study protocol and another 5 did not use exercise games as intervention in the study. Therefore, a total of 6 articles representing 6 exergame interventions project were included in this review.

\section{Data extraction and synthesis}

Data extracted from the selected articles included the following:(1) publication years and authors ; (2) sample characteristics such as size, age, gender and weight status; (3) research design (control group, game play setting, intervention tool used, duration of the study project, duration of intervention episode, total intervention duration); (4) game characteristics (type of exergame used, number of participants per session, intensity); (5) the intervention goal; (6) obesity related outcome; (7) the successful status of intervention to reduce weight among participant.

\section{Research questions}

The research questions that guided this systematic review: what is the effectiveness of exercise gaming as intervention for childhood obesity?

\section{RESULTS}

Characteristic of included studies

Study details are listed in Table 1. 


\begin{tabular}{|c|c|c|c|c|c|}
\hline Author & $\begin{array}{l}\text { Study } \\
\text { population }\end{array}$ & $\begin{array}{l}\text { Study } \\
\text { design }\end{array}$ & Tools & Outcome & Discussion \\
\hline $\begin{array}{l}\text { (Carrasco } \\
\text { et al. 2015) }\end{array}$ & $\begin{array}{l}7 \text { to } 10 \\
\text { years }\end{array}$ & $\begin{array}{l}\text { Tntervention } \\
\text { study (Pilot } \\
\text { study) }\end{array}$ & $\begin{array}{l}\text { Using Nintendo Wii } \\
\text { console }\end{array}$ & $\begin{array}{l}\text { There were reductions in } \\
\text { body mass, BMI, abdominal } \\
\text { circumference, and } \\
\text { respiratory rate while at } \\
\text { rest, as well as systolic } \\
\text { pressure after the } 6- \\
\text { minute walking test. }\end{array}$ & $\begin{array}{l}\text {-Small sample as it } \\
\text { is a pilot study }\end{array}$ \\
\hline $\begin{array}{l}\text { (Christison } \\
\text { et al. 2016) }\end{array}$ & $\begin{array}{l}\text { 8-12 years } \\
\text { old }\end{array}$ & $\begin{array}{l}\text { Randomized } \\
\text { controlled } \\
\text { trial } \\
\text { (unblinded) }\end{array}$ & $\begin{array}{l}\text { Dance Dance } \\
\text { Revolution, Exerbike } \\
\text { XG, Nintendo Wii } \\
\text { tennis and boxing, } \\
\text { Makoto Interactive } \\
\text { Arena, Lighspace Pay } \\
\text { Floor, Cybex Trazer, } \\
\text { Xavix system }\end{array}$ & $\begin{array}{l}\text { Use of exergaming in } \\
\text { community pediatric } \\
\text { weight management did } \\
\text { not reduce weight status } \\
\text { at the end of programming }\end{array}$ & $\begin{array}{l}\text { - Recruitment } \\
\text { problem and } \\
\text { missing data } \\
\text {-Calculated } \\
\text { sample size } 117 \\
\text { for power } 80 \%\end{array}$ \\
\hline $\begin{array}{l}\text { (Duman et } \\
\text { al. 2016) }\end{array}$ & $\begin{array}{l}11-14 \text { years } \\
\text { old }\end{array}$ & $\begin{array}{l}\text { Intervention } \\
\text { al study (pre } \\
\text { and post } \\
\text { design) }\end{array}$ & $\begin{array}{l}\text { Callisthenic and } \\
\text { aerobic } \\
\text { exercisesaimed to } \\
\text { target all muscle } \\
\text { groups using visual } \\
\text { biofeedback with } \\
\text { music and active } \\
\text { video games. } \\
\text { (not disclose the } \\
\text { manufacturer) }\end{array}$ & $\begin{array}{l}\text { An exercise program } \\
\text { applied with active video } \\
\text { games was found tohave } \\
\text { positive effects on the } \\
\text { obese state as well as on } \\
\text { the psychosocial status and } \\
\text { self-esteem of obese } \\
\text { individuals }\end{array}$ & $\begin{array}{l}\text { - Cofounders was } \\
\text { not analyzed such } \\
\text { as diet, family } \\
\text { history } \\
\text {-Need } \\
\text { comparative } \\
\text { group, }\end{array}$ \\
\hline $\begin{array}{l}\text { (Johnsen et } \\
\text { al. 2014) }\end{array}$ & $\begin{array}{l}\text { 8-11 years } \\
\text { old }\end{array}$ & $\begin{array}{l}\text { Randomized } \\
\text { controlled } \\
\text { trial }\end{array}$ & Kinect for Window & $\begin{array}{l}\text { The virtual pet succeeded } \\
\text { in motivating the } \\
\text { treatment group to } \\
\text { exercise significantly more } \\
\text { than their peers in the } \\
\text { control group, who only } \\
\text { had activity monitors and } \\
\text { the motivation from goal- } \\
\text { setting }\end{array}$ & $\begin{array}{l}\text { - Only study on } \\
\text { frequency of } \\
\text { physical } \\
\text { activities. } \\
\text { - Activities in the } \\
\text { pet game only } \\
\text { involve upper } \\
\text { limbs movements }\end{array}$ \\
\hline $\begin{array}{l}\text { (Staiano et } \\
\text { al. 2017) }\end{array}$ & $\begin{array}{l}14-18 \text { years } \\
\text { old girls }\end{array}$ & $\begin{array}{l}\text { Randomized } \\
\text { controlled } \\
\text { trial }\end{array}$ & $\begin{array}{l}\text { Dance video games } \\
\text { compatible with the } \\
\text { Kinect } ₫ \text { for the } \\
\text { Xbox } 360 \circledast \text { (Microsoft, } \\
\text { Redmond, WA) } \\
\text { gaming console. }\end{array}$ & $\begin{array}{l}\text { - Reduce subcutaneous } \\
\text { adiposity } \\
\text {-Increase trunk and spine } \\
\text { BMD }\end{array}$ & $\begin{array}{l}\text {-Significant finding } \\
\text { in subs group who } \\
\text { adhered to } \\
\text { protocol (>2600 } \\
\text { step/session) }\end{array}$ \\
\hline $\begin{array}{l}\text { (Trost et al. } \\
\text { 2014) }\end{array}$ & $\begin{array}{l}\text { overweight } \\
\text { or obese } \\
\text { children }\end{array}$ & $\begin{array}{l}\text { Randomized } \\
\text { controlled } \\
\text { trial }\end{array}$ & $\begin{array}{l}\text { *Self-selected } \\
\text { intensity. } \\
\text { a game console and } \\
\text { motion capture } \\
\text { device (Xbox and } \\
\text { Kinect; Microsoft } \\
\text { Corporation) active } \\
\text { sports game (Kinect } \\
\text { Adventures! Good } \\
\text { Science Studio, } \\
\text { Microsoft Game } \\
\text { Studios, Kinect } \\
\text { Sports; Rare, } \\
\text { Microsoft Game } \\
\text { Studios) }\end{array}$ & $\begin{array}{l}\text { intervention group } \\
\text {-Reduced BMI z score in } \\
\text { intervention group } \\
\text {-Increase daily moderate } \\
\text { to vigorous physical } \\
\text { activity in intervention } \\
\text { group whereas control } \\
\text { group reduce physical } \\
\text { activity }\end{array}$ & $\begin{array}{l}\text { - The study not } \\
\text { include boy as a } \\
\text { sample }\end{array}$ \\
\hline
\end{tabular}




\section{Type of studies}

Four out of six articles included in this systematic review were from randomized controlled trial studies and another 2 articles were from interventional studies.

\section{Population of the sample}

Sample population involved in those 6 articles were between 7 -18 years old. All studies excluded children with co-morbidities.

\section{Intervention duration/study duration}

Most of the studies duration ranged between 8 weeks to 6 months. However, one study was conducted for 72 hours looking at physical activity.

\section{Characteristic of the intervention}

Some of the studies incorporated conventional treatment on top of the exercise gaming intervention such as other physical activities, family education, classroom education, and self-directed care control. The intervention of exercise games were done in various settings, either in lab, home, health center or classroom. The setting of the exercise games also varied, either participants played alone or in groups with other participants/ family members. The intensity of these games also varied, with some being self-selected whereas the rest were directed by the researchers.

\section{DISCUSSION}

With the rapid advancement of gaming industry, the role of exercise gaming towards health, particularly obesity management in pediatric population should be further evaluated from time to time. In 2014, the contribution of exercise gaming towards improving physical activity and overall health were still inconclusive. ${ }^{16,17}$ Johnson, et al. found that gamification can have a positive impact on health and wellbeing, predominantly for health actions, though, several studies reported mixed or neutral effect. ${ }^{18}$ The results of those review articles need to be interpreted with caution due to small number of studies and methodological limitations, such as a lack of comparison of gamified interventions to nongamified versions of the intervention. ${ }^{18}$
32 studies which represented more than two decades coverage (from 1985 to 2013) were evaluated by Gao et al and argued that the potential of exergame were shadowed by the limitation of the published studies. ${ }^{15}$ Therefore, our review further evaluated studies from 2013 onwards to answer the research question and fulfill the objective.

\section{Coverage of the studies}

Researches on exergame in previous decades were mostly conducted in developed countries, predominantly in the United States. However, in this review, we can see that the developing countries also showed their interest in exploring exergame as a method to reduce obesity among children. Nevertheless, the studies in developing regions are still in their infancy whereby only small pilot study and a pre and post study were conducted. This could be driven by prevalence of childhood obesity which is increasing in the developing world. ${ }^{19}$ Similar from previous review by Gao et al., United States still dominate the intervention studies, majority being randomized controlled trials.

\section{Effects of exergame on weight}

Majority of the studies demonstrated that exercise games reduced the children's weight. Only one study did not obtain a statistically significant reduction. Based on the randomized controlled trial conducted by Trost et al. BMI z score reduced significantly in overweight and obese children who received intervention. ${ }^{20}$ The mean weight reduction of intervention group was $0.85 \mathrm{~kg}$ compared to the control group which showed mean weight reduction of $0.5 \mathrm{~kg}$. Positive outcomes were also seen in the study by Staiano et al. ${ }^{21}$ where there was a significant reduction in BMI $z$-score among subgroups who followed more than 2600 steps persession. Moreover, the pre and post study by Duman et al. demonstrated desirable outcome as their intervention managed to reduce the BMI of some participants into normal BMI class. ${ }^{22}$

However, controversy has been shown in the study conducted by Cristoson A. et al.. ${ }^{23}$ This may be due to the study being shadowed by missing outcome values and inadequate sample size to obtain an $80 \%$ of power of the study. 


\section{Effect of exergame on Physical Activity}

Since obese people tend to move less, exercise should not be neglected during the weight management process. Recent study by Barry et al. demonstrated that exercise games offer an added value in terms of motivation and perception regarding exercise as compared to traditional physical activities. ${ }^{24}$ Johnsen et al. measured physical activity as their primary outcome on the conducted RCT and reported significant increase in it among the intervention group by sixty percent. ${ }^{25}$ They used portable activity monitor which recorded the children's activity. The continuous monitoring provides a more sensitive evaluation for their daily physical activities. Positive results were obtained by Trost et. al. ${ }^{26}$ and another two non-randomized studies by Carrasco and Duman. ${ }^{22,26}$ In Trost's study, the intervention group seemed to have an increment in their daily moderate to vigorous activity. Meanwhile in the non-intervention group, there was a reduction of physical activity observed at the end of the study period. ${ }^{20}$ However, only Christison reported that there were no significant differences between the walking distance of two groups. ${ }^{23}$ This study seemed to have limitation to draw such conclusion due to the presence of significant outliers.

\section{Effect of Exergame on Adiposity}

Knowing that abdominal fat as one of the independent risk factors for cardiovascular disease, the intervention of exergame should be evaluated in term of its effect towards the abdominal adipose tissue. ${ }^{25}$ Previous review by Temlali and Jemni has found that exergame contributed for decrease abdominal subcutaneous adiposity, percentage of leg fat and total adiposity. ${ }^{27}$ In this review, only four studies measured abdominal circumference or adiposity as their outcome. One RCT by Staiano et al showed significant reduction of abdominal mass adiposity measured by magnetic resonance imaging (MRI). This definitive measurement by MRI offered a more accurate outcome in terms of the result. Similarly, the other two studies by Duman et al. ${ }^{22}$ and Carrasco et al. ${ }^{26}$ also showed positive effect in the reduction of the abdominal circumference after intervention. Conversely, the RCT by Christison et al. showed no significant difference in abdominal mass reduction among participants. ${ }^{23}$

\section{Effect of Exergame on Physiological and Metabolic} Changes

The effect of the exergame on physiological and metabolic changes remains inconclusive. ${ }^{28}$ There is still limited evidence to support such important changes as most studies were focused on the body mass index and physical activity. All of the studies excluded participants with co-morbid conditions, therefore the treatment effect is more difficult to be seen. Among all studies, only a small pilot study by Carrasco et al. showed promising results whereby there was a reduction of systolic blood pressure after walking test from mean $132.5( \pm 5 \mathrm{SD}) \mathrm{mmHg}$ to $110( \pm 11.5) \mathrm{mmHg} .{ }^{26}$ Majority of the studies used blood pressure as their parameters. Only Staiano et al. measured cholesterol and insulin level. ${ }^{21}$ The use of biochemical measurements such as glucose were still lacking and further studies focusing on this aspect are needed in the future.

\section{Effect of Exergame on Psychosocial Status and Self Esteem}

Since the previous decade psychosocial aspect has been emphasized by the experts in childhood weight management intervention, ${ }^{29}$ obesity management is not a one-point intervention. Therefore, it requires to address the mental health to achieve the best outcome. There are promising results from Duman et al., where they found significant improvement in depression and self-esteem scale in post intervention among obese children. ${ }^{22}$ Johnsen et al. also concluded that their study promoted self-motivation for physical activities as the intervention participation was on voluntary basis in the intervention group. ${ }^{25}$

Similarly, Christison et al. showed significant positive changes in global and physical self-worth perception but was not superior to the control group (CY-PSPP validated questionnaire). ${ }^{23}$ More studies were needed to explore on both positive and negative psychosocial effects on gadget addiction and academic performance to ensure that the outcomes do not head to undesirable effect. Nevertheless, this factor is unique and has its own distinguishable value between exercise games and current traditional weight management programme. 


\section{Effect of exergame on Screen Time}

Screen time has been associated with obesity especially in the young age population based on previous evidence. ${ }^{30,31}$ Therefore, reducing screen time is one of the targets that should be explored as an alternative programme to combat obesity. Concrete evidence between this variable is still scarce. Only Christison et al. ${ }^{23}$ looked at this parameter and found that there was a significant reduction of screen time in the intervention group.

\section{Limitation of the study}

This review only includes the studies that were published on the most recent 5 years, which is from 2013 to 2018 as we intended to review the most recent updates on the effect of exercise gaming towards childhood obesity.

Besides, the evidence of the intervention of exercise gaming in the developing countries are still limited. Only pre-and-post and one pilot study were available which met our inclusion criteria. However, we noticed that the findings from those studies are in line with the more robust randomized controlled trials in developed countries, which will support and strengthen the result.

Limitation may also be derived from the study designs, data quality of the studies, different groups and different settings of the intervention which give heterogeneity of the results. All the studies were analyzed independently by the authors, followed by inter reviewer discussion to get agreement regarding the results. Following that, a classroombased discussion on the results was conducted to get more input and opinion regarding the topics and themes discussed. Both reviewers then made their final decision based on the information obtained.

\section{Suggestion for future studies}

We found several areas that warrant further exploration to develop a high-quality evidence regarding exergaming effect towards childhood obesity as follows:

1. Long-term study to evaluate the sustainable impact of the exergaming .

2. Cost effectiveness study that can guide the policy maker for implementation of the intervention in the future.
3. The effectiveness of the intervention among obese pre-schoolers as obesity is rising drastically in this population, in parallel with screen time spent by the preschool population.

\section{CONCLUSION}

Our review found that exercise gaming is effective in reducing body mass index and adiposity, increasing physical activities and improving psychological status among school age and adolescents' groups. However, the intervention should be incorporated with other lifestyle modules in view of multifactorial involvement in childhood obesity. As a result, exercise gaming must be serve as a positive avenue for weight reduction and be utilized as an intervention to combat childhood obesity.

\section{ACKNOWLEDGEMENT}

The authors would like to express their deepest gratitude to UKM which had provided assistance for this publication via a research grant GUP-2017-061.

\section{REFERENCES}

1. Brown A. Media Use by Children Younger Than 2 Years. Pediatrics [Internet] . 2011 Nov 1 [cited 2019 Jun 12 ];128(5):1040-5. Available from: http://pediatrics.aappublications.org/cgi/ doi/10.1542/peds.2011-1753

2. Chonchaiya W, Sirachairat C, Vijakkhana N, Wilaisakditipakorn T, Pruksananonda C. Elevated background TV exposure over time increases behavioural scores of 18-month-old toddlers. Acta Paediatr [Internet]. 2015 Oct 1 [cited 2019 Jun 12];104(10):1039-46. Available from: http:// doi.wiley.com/10.1111/apa.13067

3. Domingues-Montanari S. Clinical and psychological effects of excessive screen time on children. J Paediatr Child Health [Internet]. 2017 Apr 1 [cited 2019 Jun 12];53(4):333-8. Available from: http://doi.wiley.com/10.1111/ jpc.13462

4. Zhang G, Wu L, Zhou L, Lu W, Mao C. Television watching and risk of childhood obesity: a meta-analysis. Eur J Public Health [Internet]. 2016 Feb 1 [cited 2019 Jun 12];26 (1):13-8. available from: https:// 
academic.oup.com/eurpub/article-lookup/ doi/10.1093/eurpub/ckv213

5. Stiglic N, Viner RM. Effects of screentime on the health and well-being of children and adolescents: a systematic review of reviews. BMJ Open . 2019 ;9(1):e023191. Available from: http:/ /www.ncbi.nlm.nih.gov/ pubmed/30606703

6. Dube N, Khan K, Loehr S, Chu Y, Veugelers P. The use of entertainment and communication technologies before sleep could affect sleep and weight status: a population-based study among children. Int J Behav Nutr Phys Act . $2017 ; 14(1): 97$. Available from: http:/ / www.ncbi.nlm.nih.gov/pubmed/28724380

7. Bansal S, Mahajan R. Impact of mobile use amongst children in rural area of Marathwada region of Maharashtra, India. International Journal of Contemporary Pediatrics. 2017;5 (1):50-4.

8. Sahoo K, Sahoo B, Choudhury AK, Sofi NY, Kumar R, Bhadoria AS. Childhood obesity: causes and consequences. Journal of family medicine and primary care. 2015;4(2):187.

9. Pietiläinen KH, Kaprio J, Borg P, Plasqui G, Yki -Järvinen $\mathrm{H}$, Kujala UM, et al. Physical inactivity and obesity: a vicious circle. Obesity. 2008;16(2):409-14.

10. World Health Organization. Report of the commission on ending childhood obesity: World Health Organization; 2016.

11. De Onis $M$, Blössner M, Borghi E. Global prevalence and trends of overweight and obesity among preschool children-. The American journal of clinical nutrition. 2010;92 (5):1257-64.

12. Strasburger VC, Jordan $A B$, Donnerstein $E$. Health effects of media on children and adolescents. Pediatrics. 2010:peds. 2009-563.

13. Finco MD, Maass RW, editors. The history of exergames: promotion of exercise and active living through body interaction. Serious Games and Applications for Health (SeGAH), 2014 IEEE 3rd International Conference on; 2014: IEEE.

14. Vernadakis $N$, Papastergiou $M$, Zetou $E$, Antoniou $\mathrm{P}$. The impact of an exergame-based intervention on children's fundamental motor skills. Computers \& Education. 2015;83:90102.

15. Gao Z, Chen S. Are field-based exergames useful in preventing childhood obesity? A systematic review. Obesity Reviews. 2014;15 (8):676-91.

16. Johnson D, Deterding S, Kuhn K-A, Staneva A, Stoyanov S, Hides L. Gamification for health and wellbeing: A systematic review of the literature. Internet Interventions. 2016;6:89106.

17. D. ST, J. LS, R. LR. Gaming Your Way to Health: A Systematic Review of Exergaming Programs to Increase Health and Exercise Behaviors in Adults. Games for Health Journal. 2017;6(3):136-46.

18. Johnson D, Deterding S, Kuhn K-A, Staneva A, Stoyanov S, Hides L. Gamification for health and wellbeing: A systematic review of the literature. Internet Interventions. 2016;6:89106.

19. Gupta N, Goel K, Shah P, Misra A. Childhood obesity in developing countries: epidemiology, determinants, and prevention. Endocrine reviews. 2012;33(1):48-70.

20. Trost SG, Sundal D, Foster GD, Lent MR, Vojta D. Effects of a pediatric weight management program with and without active video games: a randomized trial. JAMA pediatrics. 2014;168 (5):407-

21. Staiano A, Marker A, Beyl R, Hsia D, Katzmarzyk P, Newton R. A randomized controlled trial of dance exergaming for exercise training in overweight and obese adolescent girls. Pediatric obesity. 2017;12 (2):120-8

22. Duman F, Kokaçya MH, Doğru E, Katayıfcı N, Canbay Ö, Aman F. The Role of Active VideoAccompanied Exercises in Improvement of the Obese State in Children: A Prospective Study from Turkey. Journal of clinical research in pediatric endocrinology. 2016;8(3):334.

23. Christison AL, Evans TA, Bleess BB, Wang $H$, Aldag JC, Binns HJ. Exergaming for Health: A Randomized Study of Community-Based Exergaming Curriculum in Pediatric Weight Management. Games for health journal. 2016;5 (6):413-21.

24. Barry G, van Schaik P, MacSween A, Dixon J, Martin D. Exergaming (XBOX Kinect ${ }^{\mathrm{TM}}$ ) versus traditional gym-based exercise for postural control, flow and technology acceptance in healthy adults: a randomised controlled trial. BMC Sports Science, Medicine and Rehabilitation. 2016;8(1):25.

25. Johnsen K, Ahn SJ, Moore J, Brown S, 
Robertson TP, Marable A, et al. Mixed reality virtual pets to reduce childhood obesity. IEEE transactions on visualization and computer graphics. 2014;20(4):523-30.

26. Carrasco AC, Kerppers II, Teixeira ABP, W. JA. Assessment of functional capacity and body composition of overweight children after an aerobic exercise program using the Nintendo Wii console: A pilot study. . Medical Science Technology 2015;54(1): :93-8.

27. Effects of Different Types of Exergaming on Physiological Responses in Different Age Groups Any Good for Countries with Hot Climates? Literature Review, https:// symbiosisonlinepublishing.com/obesity-control -therapies/obesity-control-therapies41.php

28. Exergaming and obesity in youth: current perspectives. International journal of general medicine 9:275-284.

29. Tershakovec AM. Psychological considerations in pediatric weight management. Obesity research. 2004;12(10):1537-8.

30. Mitchell JA, Rodriguez D, Schmitz KH, AudrainMcGovern J. Greater screen time is associated with adolescent obesity: a longitudinal study of the BMI distribution from ages 14 to 18 . Obesity. 2013;21(3):572-5.

31. Promoting Exercise Self-Efficacy with an Exergame. Journal of Health Communication 16(2):148-162. 